\title{
Evaluation of Desiccated and Deformed Diaspores from Natural Building Materials
}

\author{
Tamás Henn ${ }^{1^{*}}$ and Róbert W. Pál ${ }^{1,2}$
}

Author Addresses: ${ }^{1}$ Department of Ecology, Institute of Biology, Faculty of Sciences, University of Pécs, Ifjúság u. 6., H-7624, Pécs, Hungary. ${ }^{2}$ Division of Biological Sciences and the Institute on Ecosystems, University of Montana, Missoula 59812, Montana, USA.

*Corresponding author: henn.tomi@gmail.com

Abstract: With the increasing sophistication of paleoethnobotanical methods, it is now possible to reconstruct new aspects of the day-to-day life of past peoples, and, ultimately, gain information about their cultivated plants, land-use practices, architecture, diet, and trade. Reliable identification of plant remains, however, remains essential to the study of paleoethnobotany, and there is still much to learn about precise identification. This paper describes and evaluates the most frequent types of deformed desiccated diaspores revealed from adobe bricks used in buildings in Southwestern Hungary that were built primarily between 1850 and 1950. A total of 24,634 diaspores were recovered from $333.05 \mathrm{~kg}$ adobe samples. These seeds and fruits belong to 303 taxa, and the majority were arable and ruderal weed species. A total of $98.97 \%$ of the diaspores were identified to species. In other cases, identification was possible only to genus or family $10.93 \%$ and $0.10 \%$ of diaspores, respectively). Difficulties in identification were caused mainly by morphological changes in the size, shape, color, and surface features of diaspores. Most diaspores were darker in color and significantly smaller than fresh or recently desiccated seeds and fruits. Surface features were often absent or fragmented. The most problematic seeds to identify were those of Centaurea cyanus, Consolida regalis, Scleranthus annuus and Daucus carota ssp. carota, which are discussed in detail. Our research aids archaeobotanists in the identification of desiccated and deformed diaspores.

Keywords: archaeobotany, desiccated seeds, deformity, seed identification, thousand seed weight

Supplementary Files available at ojs.ethnobiology.org/index.php/ebl.

\section{Introduction}

Plant remains from archaeological excavations offer direct evidence of species presence and imply direct interrelationships between humans and plants in the past (Ford 1979; Gyulai 2001; Paušič et al. 2010). Plant remains can reflect many aspects of past societies from past land-use practices, to diet, architecture and trade, as well as information about the natural environment (McGovern et al. 1995; Miller 1989). As a result, the reconstruction of historical flora requires the correct identification of archaeobotanical remains (Cappers and Neef 2012; Pearsall 2000). Accurate identification depends mainly on the quality of the botanical material recovered from excavations as well as the quality of the analysis and interpretation of such remains (Antolín 2012; Csontos 2001; van der Veen 2007).

The accurate identification of diaspores from modern seed banks is often difficult (Conn 1984; Gross 1990); the identification of seeds and fruits from archaeological sites is even more complicated and often misleading (Pearsall 2000). Although there are many special seed atlases and reference books available for the identification of recent diaspores (e.g. Bojňanský and Fargašová 2007; Cappers et al. 2006; Delcourt et al. 1979; Liu et al. 2008), their use does not ensure successful identification of archaeologically excavated diaspores. Pearsall (2000) suggested that only a limited number of characteristics can be used to identify seeds recovered in flotation or fine-sieve samples because taphonomic processes can change them appreciably. Archaeological diaspores often differ in color, shape, and size compared to recent seeds. Moreover, chemical or biochemical processes can also change the appearance of excavated diaspores (Gyulai 2001; Hillman et al. 1993).

Many studies in the last few decades have dealt with the identification of charred seeds and fruits, which constitute the most studied types of archaeobotanical remains (see e.g. Goette et al. 1994; Pearsall 


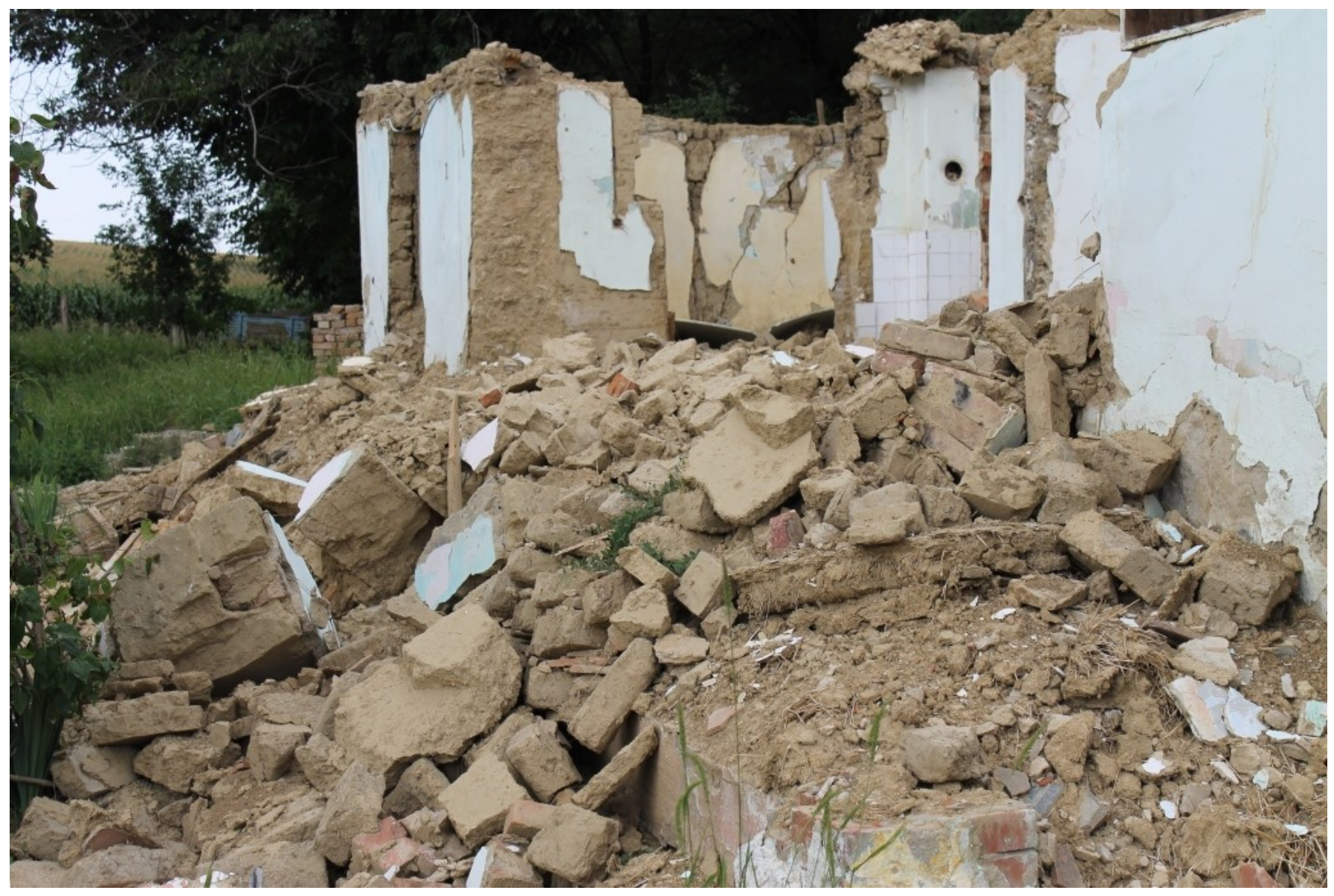

Figure 1. Ruinous cob cottage in Rózsafa (2012) with adobe bricks.

2000; Renfrew 1973; Stewart and Robertson 1971; van der Veen 2007). Moreover, detailed overviews on the properties of waterlogged and desiccated diaspores have been published recently (e.g. Cappers and Neef 2012; Hosch and Zibulski 2003; Jacomet 2013; Matthews 2010; Pearsall 2000; van der Veen 2007; Vandorpe and Jacomet 2007). Several papers on desiccated plant material discuss difficulties of identification related to diaspore deformation, but, problematically, most do not provide detailed descriptions of deformation morphology.

Although the richest sources of desiccated plant remains from the last few centuries come from natural building materials, with added straw and chaff (Zohary et al. 2012), palaeoethnobotanical analysis of these materials in Europe is uncommon (Ernst and Jacomet 2005). Many studies demonstrate that old buildings and building materials such as adobe and mud bricks (Hendry 1931; Hendry and Bellue 1936; Hendry and Kelly 1925; O’Rourke 1983; Paušič et al. 2010), daub (Carruthers 1991), filling material for floor cavities (Ernst and Jacomet 2005; Fischer and Rösch 1999; Lohmann 1987), roofing materials (de Moulins 2007; Willerding 1996), and other materials (Dickson 1996; Latałowa et al. 2003) are rich sources of desiccated plant micro- and macro-remains, especially seeds and fruits. Despite good preservation, difficulties in identification of desiccated diaspores has not been addressed (Day 2013; Hendry and Bellue 1936). In our previous research (Henn et al. in press), a large number of, poorly preserved, desiccated diaspores were recovered and evaluated from 60-160 year old adobe bricks from Southwestern Hungary. In this study we discuss the preservation status of recovered desiccated seeds and fruits, particularly focusing on deformation. The present study summarizes common morphological changes of desiccated diaspores and provides details for improved identification methods.

\section{Materials and Methods}

Collecting and processing of adobe samples 


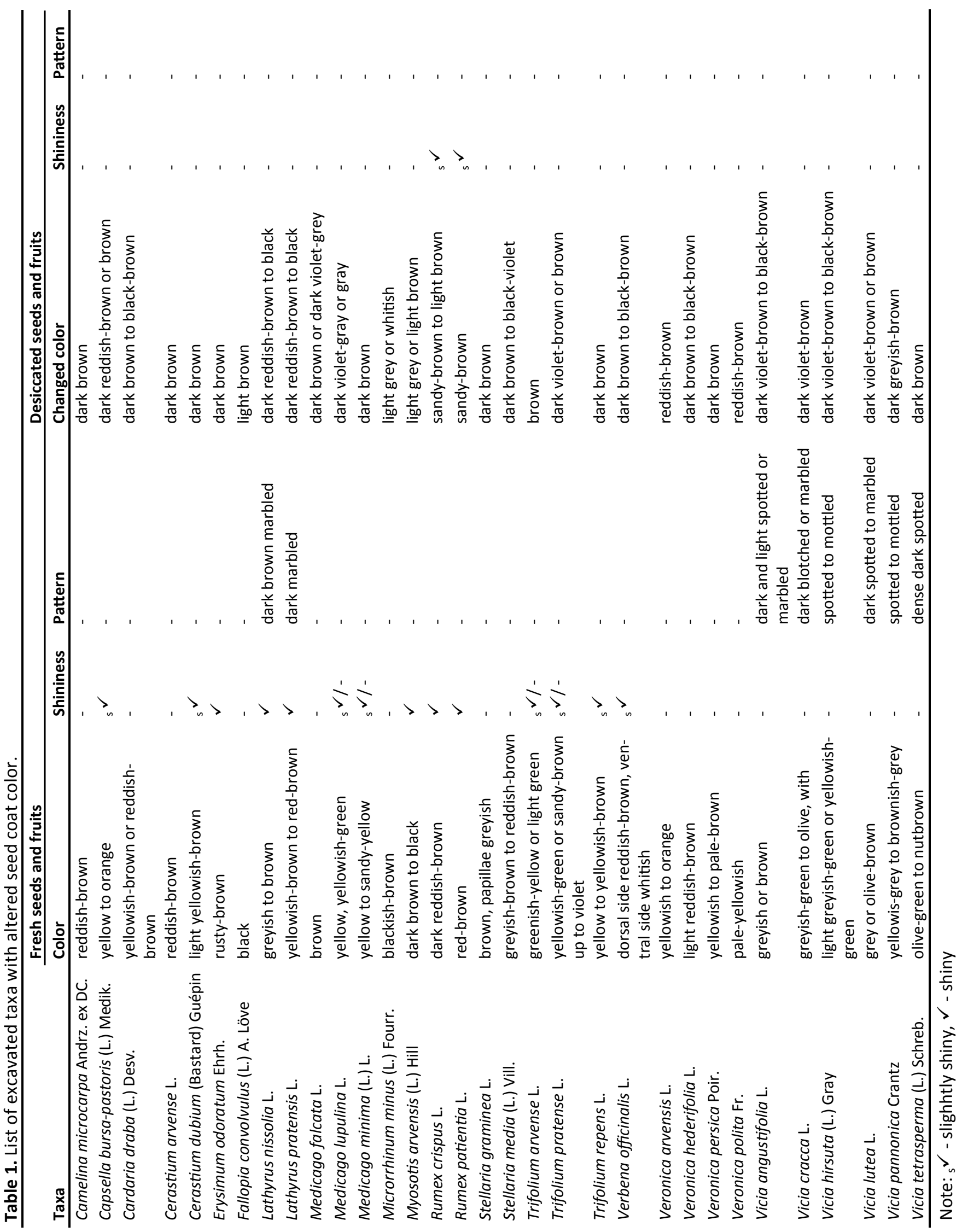




\section{(f) Ethnobiolocy Letters}

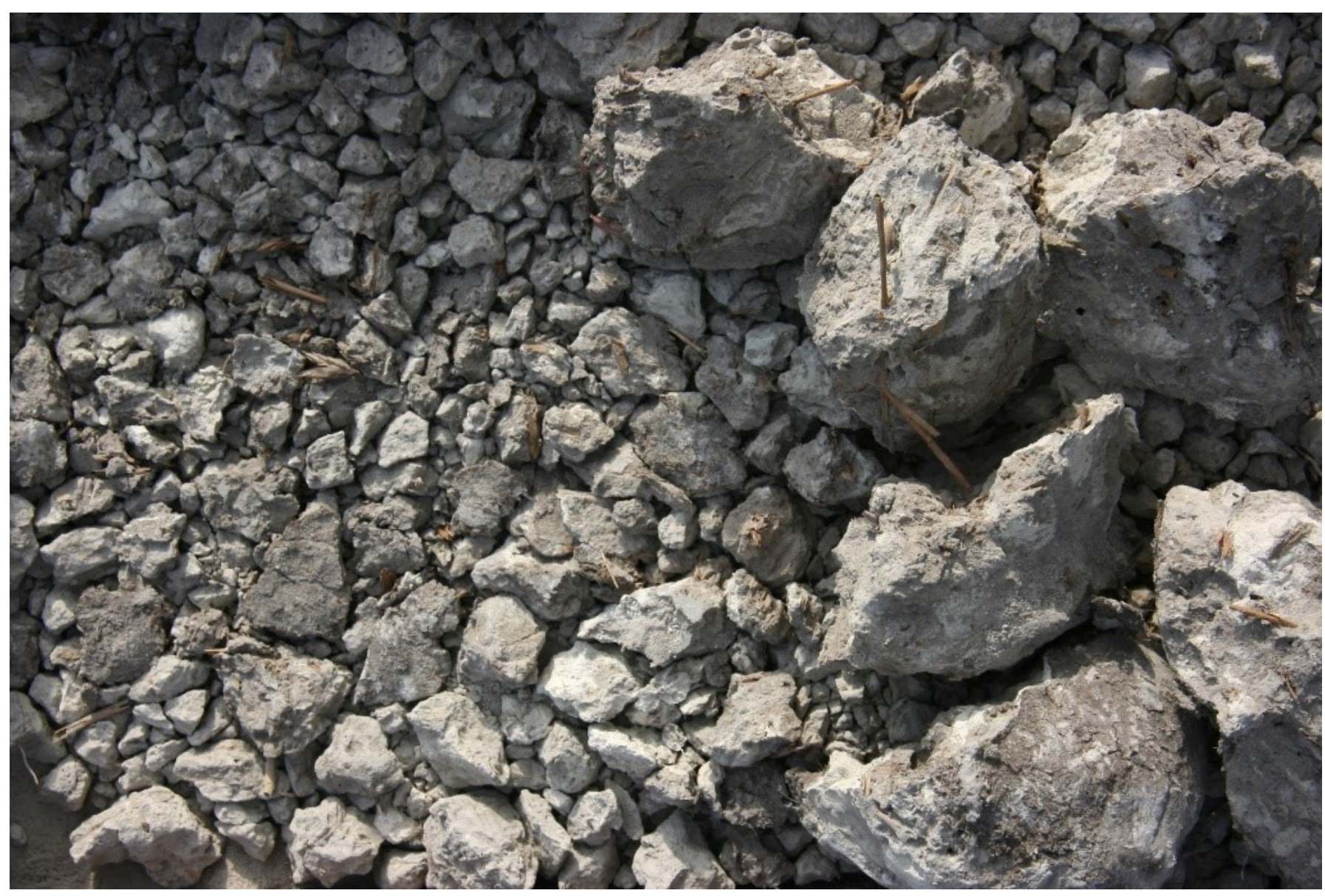

Figure 2. Crushed adobe brick sample.

In total, 60 adobe brick samples (330.05 kg) were collected from 29 settlements from old untenanted and/or ruinous cob cottages (Figure 1) in Southwestern Hungary (see Supplementary Table 1). Most of the bricks were constructed between 1850 and 1950 . In some cases, the year of building construction was known (e.g., signed on the pediments), but in other cases construction could only be dated to the decade based on information from the owners or neighbors. Adobe bricks were typically made of local building materials near construction sites (Büki 2003; Juhász 1991). Preserved plant remains in bricks are representative of local anthropogenic flora, including plants cultivated in surrounding arable fields, vineyards, and home gardens.

To recover plant remains, the bricks were crushed using a simple hammer and a ceramic mortar. Our preliminary investigation (Henn et al. in press) shows that desiccated plant macro-remains are resistant to crushing and other mechanical impacts, as fragmentation of desiccated diaspores was insignificant during recovery. Refuse (Figure 2) was sifted over sieves of 2.0, 1.0 and $0.5 \mathrm{~mm}$ mesh size to remove most of the loam. After dry-sieving, extraction by flotation (Malone 1967) was used to separate the organic plant material (chaff, straw, fruits, seeds, etc.) from the inorganic components of adobe. Common salt (sodium chloride, $\mathrm{NaCl}$ ) solution with $1.1261 \mathrm{~g} \mathrm{~cm}^{-3}$ specific gravity was used as flotation medium (Gonzalez and Ghermandi 2012; Henn et al. in press). The supernatant was processed using a $0.25 \mathrm{~mm}$ sieve after sedimentation, which was then rinsed under tap water and air-dried. Our previous investigation also showed that diaspores of all preserved taxa were present in the supernatant (Henn et al. in press). The recovered and desiccated plant material consisted mainly of chaff and straw (Figure 3), which are typical constituents of adobe, but also contained fruits and seeds of cultivated and wild plants.

Separation, identification and analysis of the recovered diaspores The final step in analysis was hand-sorting of the 
Table 2. List of excavated taxa with degraded seed surface features.

\begin{tabular}{|c|c|c|}
\hline Taxa & Deformed/abraded structure & Degradation \\
\hline Bidens tripartita $\mathrm{L}$. & spines & partly/completely \\
\hline Caucalis platycarpos $\mathrm{L}$. & spines & partly \\
\hline Centaurea cyanus L. & crest/fruit coat & partly/completely \\
\hline $\begin{array}{l}\text { Centaurea stoebe ssp. micranthos } \\
\text { (Gugler) Hayek }\end{array}$ & crest & completely \\
\hline Chelidonium majus $\mathrm{L}$. & ventral aril & completely \\
\hline Consolida regalis Gray & ving-list lobates/seed coat & partly/completely \\
\hline Crepis biennis L. & crest & completely \\
\hline Crepis rhoeadifolia M. Bieb. & crest & completely \\
\hline Crepis tectorum $\mathrm{L}$. & crest & completely \\
\hline Daucus carota ssp. carota L. & spines/spiny ridges & partly/completely \\
\hline Hieracium pilosella $\mathrm{L}$. & crest & partly \\
\hline Lactuca saligna $\mathrm{L}$. & crest & partly/completely \\
\hline Lactuca serriola $\mathrm{L}$. & crest & completely \\
\hline Lappula squarrosa (Retz.) Dumort. & prickles & partly \\
\hline Leontodon autumnalis L. & crest & completely \\
\hline Pastinaca sativa $\mathrm{L}$. & verge & partly \\
\hline Ranunculus arvensis $\mathrm{L}$. & spines & partly \\
\hline Scleranthus annuus L. & perianth/sepals & partly/completely \\
\hline Scorzonera sp. L. & crest & completely \\
\hline Sonchus arvensis $\mathrm{L}$. & crest & completely \\
\hline Sonchus asper (L.) Hill & crest & completely \\
\hline Sonchus oleraceus L. & crest & completely \\
\hline Taraxacum officinale Weber & crest & partly/completely \\
\hline Tilia sp. L. & wing & completely \\
\hline Tordylium maximum L. & verge/strerchers & partly \\
\hline Torilis arvensis (Huds.) Link & spines/seed coat & partly/completely \\
\hline Tragopogon orientalis L. & crest & completely \\
\hline Turgenia latifolia (L.) Hoffm. & spines & partly \\
\hline Xanthium spinosum $\mathrm{L}$. & spines/thornes & partly \\
\hline Xanthium strumarium L. & spines/thornes & partly \\
\hline
\end{tabular}

diaspores under a binocular stereomicroscope (Leica Zoom 2000 - Model No. Z45V). The seeds and fruits were identified using special seed atlases and reference books (Bojňanský and Fargašová 2007; Hunyadi et al. 2000; Király et al. 2011; Radics 1998; Schermann 1967) and also an extensive reference collection of seeds and fruits from synanthropic plant species of the region. The difficulties of identification (changes in color, shape, surface structures, size, etc.) were described and also illustrated in some cases. Thousand-seed weights (TSW) of 13 species were measured on laboratory analytical scales and compared to literature data to determine changes in seed size (Radics 1998; Schermann 1967). Statistical analyses were carried out using PAST software (Hammer et al. 2001). The Shapiro-Wilk Test was performed to assess whether or not the data were normally distributed. Because the data were not normally distributed, the Wilcoxon Signed-Rank Test was then used for comparison of thousand-seed weights. The nomenclature of plant species follows Király (2009).

\section{Results}

Evaluation of recovered diaspores

Our results indicate that natural building materials in Hungary contain a large amount of plant remains. A total of 24,634 desiccated diaspores were recovered from $333.05 \mathrm{~kg}$ of adobe samples, which belonged to 303 taxa. Cereal crop remains (mostly chaff and straw) are dominant in the recovered plant material; seeds of domesticated and other cultivated plants account for $4.73 \%$ of the diaspores. A total of 15 cultivated 


\section{(f) Ethnobiolocy Letters}

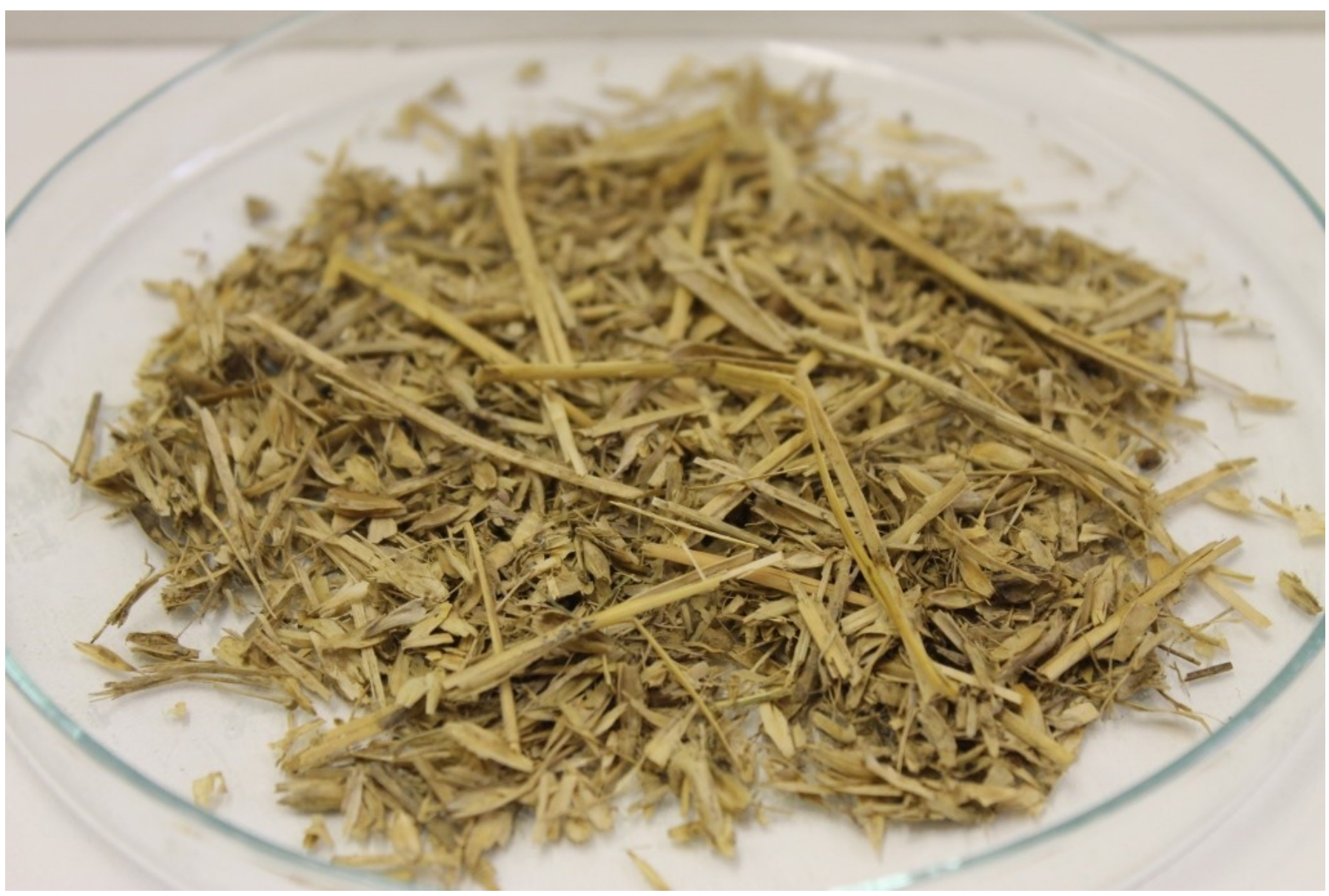

Figure 3. Desiccated plant material from sample AB05 (Olasz).

species were identified. The proportion of Triticum aestivum L. seeds is the highest, but numerous seeds of Avena sativa L., Brassica 'napus ssp. napus L., Papaver somniferum L. and Vitis vinifera $\mathrm{L}$. were also identified. Interestingly, stones of some fruit-trees, e.g. Amygdalus communis L., Juglans regia L., Persica vulgaris Mill. and Prunus domestica L. were also found in the studied samples.

In addition, $95.27 \%$ of the recovered diaspores are from wild plants, most are weed species associated with arable (Secalietea), ruderal (Chenopodietea), and roadside (Artemisietea) vegetation. Within the arable species, there are many cereal weeds (e.g. Agrostemma githago L., Bromus secalinus L., Centaurea cyanus L., Papaver rhoeas L., Ranunculus arvensis L.) and also stubble weeds (e.g. Ajuga chamaeptys (L.) Schreb, Consolida regalis Gray, Euphorbia falcata L., Kickxia spuria (L.) Dumort., Stachys annua L.). A large number of noxious ruderal and roadside weed species (e.g. Amaranthus L. spp., Chenopodium L. spp., Rumex L. spp., Sambucus ebulus L., Verbena officinalis L.) were also recovered. In addition to the dominant weed species, several grassland, wetland, and woodland species have also been recovered from the adobe bricks. For the entire list of identified taxa see Supplementary Table 1.

\section{Preservation and deformation of excavated diaspores}

The preservation condition of desiccated diaspores from our adobe samples is excellent. A total of $98.97 \%$ of the excavated fruits and seeds could be identified to the species level. However, in some other cases the identification was possible only to genus $(0.93 \%$ of diaspores) or family level $(0.10 \%$ of diaspores) because morphological changes of desiccated diaspores were significant, as was fragmentation of seeds and fruits (Figure 4A). In several cases, the seed coat (the most important characteristic in the identification process) was lost or badly eroded, and proper identification became extremely difficult or impossible. Although diaspores tended to be well preserved in this study, there is important taphonomic information related to the small proportion of poorly 
Table 3. Changes in the size of desiccated diaspores - comparison of thousand-seed weight (TSW) of some excavated species to literature sources.

\begin{tabular}{lllll}
\hline & \multicolumn{2}{l}{ Thousand Seed Weight (g) } & Relative shrinkage (\%) \\
\cline { 2 - 5 } Taxa & Radics (1998) & Schermann (1967) & Adobe bricks & 61.85 \\
\hline Amaranthus retroflexus & $0.3-0.5$ & $0.3-0.5$ & $0.118-0.185^{\mathrm{a}}$ & 62.49 \\
L. & $0.4-0.8$ & $0.4-0.7$ & $0.178-0.229^{\mathrm{b}}$ & 40.61 \\
Anagallis arvensis L. & & $0.12-0.17$ & $0.079-0.090^{\mathrm{a}}$ & 47.27 \\
Apera spica-venti (L.) P. & 0.12 & $2.8-3.8$ & $1.700^{\mathrm{c}}$ & 62.48 \\
Beauv. & $2.8-3.8$ & $0.8-1.0$ & $0.318-0.494^{\mathrm{a}}$ & 77.11 \\
Centaurea cyanus L. & $0.8-1.8$ & $1.1-1.3$ & $0.247-0.385^{\mathrm{b}}$ & 45.45 \\
Chenopodium album L. & $5.5-8.2$ & $3.592^{\mathrm{c}}$ & 81.31 \\
Cirsium arvense (L.) Scop. & 2.0 & 1.15 & $0.207-0.223^{\mathrm{b}}$ & 21.11 \\
Datura stramonium L. & $5.5-8.2$ & $0.08-0.1$ & $0.077-0.084^{\mathrm{a}}$ & 42.19 \\
Geranium molle L. & 1.15 & $0.7-2.7$ & $0.819-1.102^{\mathrm{b}}$ & 36.25 \\
Papaver rhoeas L. & $0.09-0.15$ & $0.8-1.2$ & $0.612^{\mathrm{c}}$ & 19.18 \\
Polygonum aviculare L. & 2.7 & $0.3-0.38$ & $0.276^{\mathrm{c}}$ & 48.80 \\
Stachys annua L. & $0.8-1.2$ & $4.1-6.2$ & $2.148-3.122^{\mathrm{a}}$ & \\
Verbena officinalis L. & $0.3-0.38$ & & & \\
Vicia hirsuta (L.) Gray & $4.0-6.5$ & & & \\
\hline
\end{tabular}

${ }^{\mathrm{a}} 3 \times 100$ seeds weighed

${ }^{b} 2 \times 100$ seeds weighed

'100 seeds weighed

preserved diaspores. In the following sections, we discuss the most significant changes of desiccated diaspores recovered from adobe bricks.

\section{Changes in seed coat color}

Many of the excavated diaspores differ in color from the recent material. Most of these diaspores absorbed a notably darker brown, reddish-brown, or black color (Table 1). In our findings, Brassicaceae, Caryophyllaceae, and Scrophulariaceae species were the most dominant (Figure 4B and C). Also, seeds of some Fabaceae species, especially Lathyrus L. and Vicia L. taxa (e.g. Vicia hirsuta (L.) Gray, Figure 4D), became not only darker, but their characteristic spots and marbled patterns completely disappeared from the surfaces of seed coats. In contrast, we also found many diaspores that became a lighter brown or grey (e.g. Fallopia convolvulus (L.) A. Löve, Microrrbinum minus (L.) Fourr., Myosotis arvensis (L.) Hill and some Rumex L. species). In addition, lustrous and glossy seed coats generally became dull.

\section{Changes in the shape of diaspores}

Our research indicates that desiccated diaspores from building materials often become degraded and that surface features are often abraded. This phenomenon hampers the correct identification of many diaspores recovered from adobes, e.g. Caucalis platycarpos L.,
Chelidonium majus L. (Figure 4E), Consolida regalis Gray, Daucus carota L., Lactuca L. spp., Lappula squarrosa (Retz.) Dumort., Ranunculus arvensis L. (Figure 4F), Sonchus L. spp., Turgenia latifolia (L.) Hoffm. (Figure 4G), Xanthium L. spp. and other Asteraceae species (see Table 2). Biological and/or chemical degradation of diaspores was also observed in some cases if the adobe sample got wet before recovery. In our samples, only a few diaspores (e.g. Amaranthus retroflexus L. and Chenopodium album L.) were affected. Also, many 'hollow' grains were found in the samples, from which the endosperm had disappeared but in which the hulls maintained their original seed shapes or became plastic. Such diaspores (e.g. C. album, F. convolvulus and $T$. aestivum) are usually extremely fragile.

Changes in the size of diaspores

Although TSW is characteristic for species, seed weights could not be used to identify seeds because of the significant weight changes of desiccated diaspores. We compared the seed size of 13 recovered species to recent material. Our data show a significant decrease in size (Wilcoxon Signed-Rank Test; $\mathrm{t}=3.108$, df $=$ $12, p=0.00037$ ) of the recovered seeds from expected (recent) values (Table 3). Use of seed weight for identification is also problematic if there are many 'hollow' grains within the recovered diaspores of examined taxa as this changes TSW dramatically (e.g. 

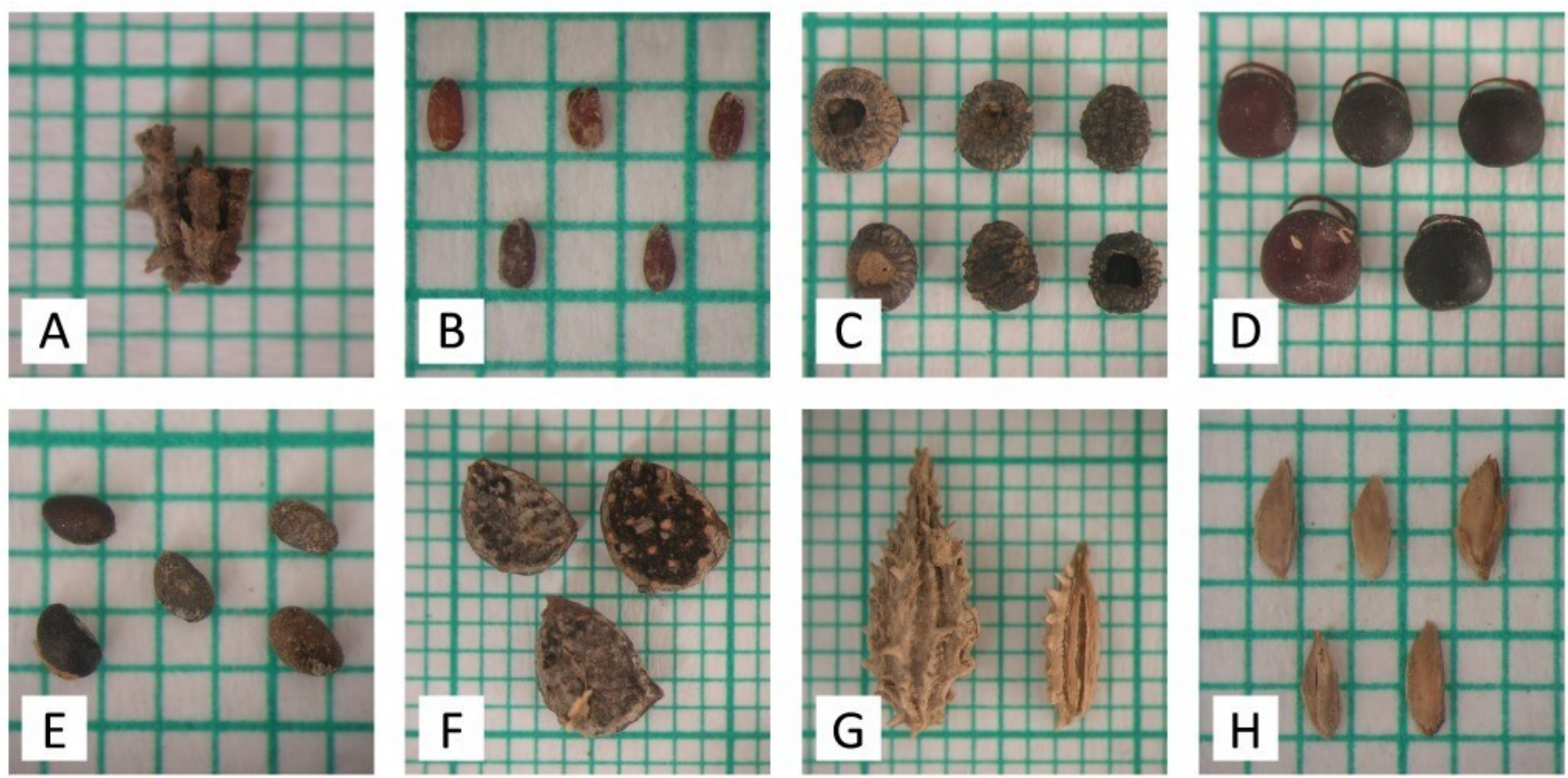

Figure 4. Deformed diaspores: fragmented achene of Caucalis platycarpos (A), discolored seeds of Capsella bursa-pastoris (B), Veronica hederifolia (C) and Vicia hirsuta (D), abraded diaspores of Chelidonium majus (E), Ranunculus arvensis (F) and Turgenia latifolia (G), chaff-like seeds of Cynodon dactylon $(\mathrm{H})$.

\section{Chenopodium album L., Cirsium arvense (L.) Scop.).}

\section{Other difficulties of identification}

The correct identification of desiccated diaspores can also be influenced by several other factors. We found many similar diaspores of Papaver L., Potentilla L., Silene L. and some Asteraceae and Poaceae species (e.g. Poa annua/P. trivialis) that were difficult to identify. We also experienced difficulty in the case of Poaceae species, as many of these diaspores (e.g. Figure 4H) were morphologically similar to other plant remains (e.g. chaff, stem and leaf fragments).

Deformation of seeds and fruits can be problematic during identification, and neither reference books nor reference collections can solve these problems. For that reason, we emphasize the diapsores of four species below that were exceptionally difficult to identify because we encountered intact and eroded diaspores that were diverse in terms of diagnostic characteristics. Eroded diaspores could not be identified unless partially eroded forms were recovered. These partially eroded forms served as a midpoint reference in the continuum of erosion, and greatly aided in the correct identification of completely eroded diaspores. New criteria for identification for each of the species is described in detail below; photos that are referred to for each species are presented in Appendix 1.

\section{Centaurea cyanus L. (cornflower)}

Characteristic achenes of cornflower (Photo 1A) were always recognizable in the desiccated plant material. On the other hand, highly eroded seeds (Photo 1B) were also encountered that completely differed from the crested achenes of cornflower (Photo 2). Based on our observation, the eroded seed is cylindrical, but a bit stocky, 2.5-3.0 $1.2-1.5 \mathrm{~mm}$. The base is lengthened, $0.5-1.0 \mathrm{~mm}$, and other features and the outer seed coat are totally absent. The surface is smooth, light brown to dark brown or dark purple-brown and dull.

\section{Consolida regalis Gray (forking larkspur)}

Like the achenes of cornflower, seeds of forking larkspur (Photo 3A) are also recognizable. However, we also found some eroded seeds (Photo 3B) from which the characteristic wing-like flakes and the outer seed coat were totally abraded. The eroded seed is ovate, obovate, or almost roundish, 1.4-1.8 '1.0-1.2 $\mathrm{mm}$. The hilum forms a small pinnacle on the base, while the apex is almost rounded with an expressed annulus. The surface is smooth, yellow to brown, and dull. 


\section{Scleranthus annuus L. (annual knawel)}

Undamaged capsules (Photo 4A) of annual knawel were not found in our samples. The recovered fruits (Photos 4B and 5) are deformed, sepals are parceled (remains of harder main and lateral veins could be found as spikes or stumpy spikes, 2.0-3.5 ' 1.3-1.5 $\mathrm{mm})$, or are totally abraded (1.4-1.8 $1.3-1.5 \mathrm{~mm})$. The surface is even more waved or ribbed, the neck is more pronounced, and color is yellowish-grey to light brown and dull.

\section{Daucus carota ssp. carota L. (wild carrot)}

We did not find undamaged achenes (Photo 6A) of wild carrot. The spiny secondary ridges are partially or, in most cases, totally abraded from the dorsal side of achenes. The eroded achene (Photo 6B) is ellipsoid, the non-spiny ridges are visible, the lateral spiny ridges are absent, and the medials are reduced to simple ribs, $2.4-3.0$ ' $1.2-1.5 \mathrm{~mm}$. The surface is smooth, brownish-grey or dark brown to black, and dull.

\section{Discussion}

The main focus of archaeobotanical research is to study people/plant relationships, including the reconstruction of agricultural strategies, diet, the social and cultural roles of food, the exploitation of wild resources, and the production of fodder (van der Veen 2007). Ernst and Jacomet (2005) and Paušič et al. (2010) demonstrated that the analysis of desiccated plant remains from natural building materials can be used to reconstruct contemporary house constructions, plant cultivation methods, crop processing procedures, and other kinds of human activities. However, to obtain accurate reconstructions, it is essential to correctly identify archaeobotanical remains. This overview of the effects of diaspore preservation on identification can be of aid to researchers who study fruits and seeds from archaeological sites and from natural building materials.

The archaeobotanical study of plant materials preserved in mud bricks and daub or other building structures is important in arid regions, such as North Africa (e.g. Marinova et al. 2012; Newton 2004; van der Veen 1999), but is rare in the temperate region of Europe (see e.g. Carruthers 1991; Ernst and Jacomet 2005; Paušič et al. 2010). While desiccated North African assemblages originate from a wide range of contexts (pit fills, middens, hearths, dung, wall plaster, mud brick, etc.), those from Europe originate from one specific context: cob and adobe buildings of medieval and later dates (van der Veen 2007). Our examination of adobe bricks from the $19^{\text {th }}$ and early $20^{\text {th }}$ centuries shows that natural building materials contain a large number of plant remains. Many different kinds of plant materials (mainly cereal chaff and straw) were used for tempering adobe bricks in Hungary. Similar to the study of Hendry and Bellue (1936) and Marinova et al. (2012), a wide spectrum of diaspores of domesticated and other cultivated plants were recovered from our adobe samples. Beyond cultivated species, a large number of fruits and seeds from wild plants (mostly weed species) were recovered and identified. As Jones (1987) concluded, plant remains from archaeobotanical samples can also be products and by-products of crop processing. Hendry (1931), Hendry and Bellue (1936), and Juhász (1991) confirmed that remnants from winnowing, threshing, and other crop processing procedures were used for tempering adobe bricks. (c.f., Ernst and Jacomet 2005, Paušič et al. 2010). However, as de Moulins (2007) demonstrated, it is difficult to ascertain the origin of the incorporated taxa because of complex taphonomic processes. Further, Jones (1987) determined, that remains of wild species from archaeological samples can also originate from adobe pits and their surroundings or from courtyards and other anthropogenic and wild environments (Carruthers 1991; Green 1979; Rösch and Fischer 1999).

Identification of archaeological diaspores can be problematic. As Martin and Barkley (1961) and Schermann (1967) determined, the most useful characteristics for recognition of seeds are shape, size, peculiarities of the surface, and coloring; in most cases combinations of these features are required for a correct identification. The seed coat provides many of the most important diagnostic characteristics, including color, texture, attachments, and scars (Cappers and Neef 2012; Pearsall 2000). Changes of seed coat color of desiccated diaspores have previously been reported by Gyulai (2001), Pearsall (2000), and van der Veen (2007), but these studies did not list species or taxa. In our investigation, several discolored diaspores were identified; these taxa are listed in Table 1 and color changes have been precisely documented. Pearsall (2000), van Bergen et al. (1997), and van der Veen (2007) also found that most of the discolored diaspores became notably darker and dull, and patterns disappeared from surfaces. In contrast, here many diaspores were found that lightened in color (e.g. Microrrbinum minus and Myosotis arvensis), which has not been described previously. Beyond coloring, the 
shape of diaspores also provides important diagnostic characteristics (e.g. features and peculiarities); the presence or absence of these can also significantly influence identifiability (Cappers and Bekker 2013; Radics 1998; Schermann 1967).

Preservation of desiccated diaspores is usually excellent, thus surface features and growths (hairs, wings, spikes, etc.) and papery tissues (e.g. palea and lemma) are often present (van Bergen 1997; van der Veen 2007). However, desiccated materials may also be fragile, thus preservation is primarily dependent on burial conditions (Cappers and Neef 2012; Pearsall 2000; van der Veen 2007). In addition, Pennington and Weber (2004) and Schermann (1967) suggest that specific traits of plant species may also be important factors in preservation. In our findings, most diaspores affected by degradation have different kinds of surface features (hairs, spikes, wings, etc.) (Table 2). Final identification of our degraded diaspores in many cases was only possible if intact, partially and completely degraded seeds of the same species (e.g. in the cases of Centaurea cyanus and Consolida regalis) were also recovered. This allowed direct comparison of similar seeds in different preservation stages and also comparison to seeds in reference collections (c.f. Cappers and Neef 2012; Gyulai 2001). Beyond mechanical impacts, diaspores may also be degraded by chemical and biological processes, resulting in distended, deformed materials and corroded surfaces (Gyulai 2001; Hillman et al. 1993; Pearsall 2000; van Bergen et al. 1997). However, de Moulins (2007) and Miller (1989) note that desiccated materials are usually not affected by these processes because chemical and microbial degradation is lacking or is slow in continuously dry conditions. In some cases adobe samples may have been exposed to moisture prior to recovery, thus biochemical processes may have degraded the diaspores and 'hollow' grains (van der Veen 2007) and partially decomposed seeds may form. These kinds of remains tend to be very fragile.

Seed size is another important characteristic for identification; no previous studies have reported change in size of archaeological diaspores to be problematic for identification. In this study, beyond the changes in the color and shape of the recovered diaspores, a significant change has been observed in the size of desiccated fruits and seeds (Table 3). We contend that size change must be considered as an important factor during the identification process.

\section{Conclusion}

This paper presents the most common deformation types of desiccated diaspores in adobe bricks from Southwestern Hungary and provides a species list with changes in the morphology of diaspores. This aids in the identification of desiccated fruits and seeds from natural building materials from archaeological contexts. Diaspores from many other archaeological contexts are influenced by similar taphonomic process that change size, texture, color, and shape of seed and fruit remains. Therefore, the results reported here are important for archaeobotany more broadly. The correct identification of palaeoethnobotanical plant remains is essential for producing reliable biological, ecological, and sociological data.

\section{Acknowledgements}

Authors are thankful to Dr. Andrea Stierle (The University of Montana) and to Dr. Csaba Varga (University of Pécs) for their help in the linguistic revision of the text.

\section{Declarations \\ Permissions: Not applicable.}

Sources of funding: This research was realized in the frames of TÁMOP 4.2.4. A/2-11-1-2012-0001, National Excellence Program - Elaborating and operating an inland student and researcher personal support system. The project was subsidized by the European Union and co-financed by the European Social Fund.

Conflicts of interest: None declared.

\section{References Cited}

Antolín, F. 2012. Experimental archaeology as a resource for approaching formation processes of seed assemblages. First results and future perspectives. Estrat Crític 6:35-48.

Bojňanský, V. and A. Fargašová. 2007. Atlas of seeds and fruits of Central and East-European flora. The Carpatbian Mountains region. Springer, Dordrecht.

Büki P. 2003. Különböző összetételű vályogok fizikai és mechanikai vizsgálatai. Épitóanyag 55:151-155.

Cappers, R. T. J. and R. M. Bekker. 2013. A manual for the identification of plant seeds and fruits. Barkhuis, Groningen.

Cappers, R. T. J., R. M. Bekker, and J. E. A. Jans. 2006. Digital Seed Atlas of the Netherlands. Groningen Archaeological Studies 4. Barkhuis 
Publishing, Eelde, The Netherlands.

Cappers, R. T. J. and R. Neef. 2012. Handbook of plant palaeoecology. Barkhuis, Groningen.

Carruthers, W. J. 1991. Plant remains recovered from daub from a $16^{\text {th }}$ century manor house - Althrey Hall, near Wrexham, Clwyd, UK. Circaea 8:55-59.

Conn, J. S., C. L. Cochrane and J. A. DeLapp. 1984. Soil seed bank changes after forest clearing and agricultural use in Alaska. Weed Science 32:343-347.

Csontos, P. 2001. A természetes magbank kutatásának módszerei. Scientia Kiadó, Budapest.

Day, J. 2013. Botany meets archaeology: people and plants in the past. Journal of Experimental Botany 64:112. Doi: $10.1093 / j x b / e r t 068$

Delcourt, P. A., Davis, O. K. and R. C. Bright. 1979. Bibliography of taxonomic literature for the identification of fruits, seeds, and vegetative plant fragments. Oak Ridge National Laboratory, Oak Ridge.

de Moulins, D. 2007. The weeds from the thatch roofs of medieval cottages from the south of England. Vegetation History and Archaeobotany 16:385398. Doi: $10.1007 /$ s00334-006-0035-0

Dickson, C. 1996. Food, medicinal and other plants from the $15^{\text {th }}$ century drains of Paisley Abbey, Scotland. Vegetation History and Archaeobotany 5:25-31. Doi: 10.1007/BF00189432

Ernst, M. and S. Jacomet. 2005. The value of the archaeobotanical analysis of desiccated plant remains from old buildings: methodological aspects and interpretation of crop weed assemblages. $V$ egetation History and Archaeobotany 15:45-56. Doi: 10.1007/s00334-005-0077-8

Fischer, E. and M. Rösch. 1999. Denkmalpflege, Hausforschung und Archäobotanik. Pflanzen in Lehmstrukturen historischer Gebäude als Dokumente früheren Lebens. Denkmalpflege in BadenWürttemberg 2:76-84.

Ford, R. I. 1979. Paleoethnobotany in American Archaeology. In Advances in Archaeological Method and Theory 2, edited by M.B. Schiffer, pp. 285-336. Academic Press, New York.

Goette, S., M. Williams, S. Johannessen and C.A. Hastorf. 1994. Toward reconstructing ancient maize: experiments in processing and charring. Journal of Ethnobiology 14:1-21.
Gonzalez, S. L. and L. Ghermandi. 2012. Comparison of methods to estimate soil seed banks: the role of seed size and mass. Community Ecology 13:238-242. Doi: 10.1556/ComEc.13.2012.2.14

Green, F. J. 1979. Collection and interpretation of botanical information from Medieval urban excavations in southern England. In Festschrift Maria Hopf, edited by U. Korber-Grohne, pp. 39-55. Rheinland Verlag, Cologne.

Gross, K. L. 1990. A comparison of methods for estimating seed numbers in the soil. Journal of Ecology 78:1079-1093. Doi: 10.2307/2260953

Gyulai, F. 2001. Archaeobotanika. A kulturnövények története a Kárpát-medencében a régészeti-növénytani vizsgálatok alapján. Jószöveg Kiadó, Budapest.

Hammer, O., D. A. T. Harper and P. D. Ryan. 2001. PAST: Paleoontological Statistics software package for education and data analysis. Palaeontologia Electronica 4:9.

Hendry, G.W. 1931. The adobe brick as a historical source. Agricultural History 5:110-127.

Hendry, G. W. and M. K. Bellue. 1936. An approach to Southwestern agricultural history through adobe brick analysis. In Symposium on Prebistoric Agriculture, Anthropological Series, edited by Anon., pp. 65-72. University of New Mexico Bulletin, Albuquerque.

Hendry, G. W. and M. P. Kelly. 1925. The plant content of adobe bricks. California Historical Society Quarterly 4:361-373.

Henn, T., S. Jacomet, D.U. Nagy and R.W. Pál. In press. Desiccated diaspores from building materials: methodological aspects of processing adobe bricks for archaeobotanical studies and first results of a study of earth buildings in SW-Hungary. Vegetation History and Archaeobotany. Doi: 10.1007/s00334-0140499-2

Hillman, G., S. Wales, F. McLaren, J. Evans and A. Butler. 1993. Identifying problematic remains of ancient plant foods: a comparison of the role of chemical, histological and morphological criteria. World Archaeology 25:94-121. Doi: 10.1080/00438243.1993.9980230

Hosch, S. and P. Zibulski. 2003. The influence of inconsistent wet-sieving procedures on the macroremain concentration in waterlogged sediments. Journal of Archaeological Science 30:849-857. Doi: 


\subsection{6/S0305-4403(02)00263-7}

Hunyadi, K., I. Béres and G. Kazinczi. 2000. Gyomnövények, gyomirtás, gyombiológia. Mezőgazda Kiadó, Budapest.

Jacomet, S. 2013. Archaeobotany: analyses of plant remains from waterlogged archaeological sites. In The Oxford handbook of wetland archaeology, edited by $\mathrm{F}$. Menotti and A. O’Sullivan, pp 497-514. Oxford University Press, Oxford.

Jones G. 1987. A statistical approach to the archaeological identification of crop processing. Journal of Archaeological Science 14:311-323.

Juhász A. 1991. Sármunka. In Magyar néprajz nyolc kötetben II. Kézmüvesség, edited by O. Domonkos, pp. 614-619. Akadémiai Kiadó, Budapest.

Király, G., ed. 2009. Új magyar füvészkönyv. Magyarország bajtásos növényei. I. Határoðókulcsok. Aggteleki Nemzeti Park Igazgatóság, Jósvafö.

Király, G., V. Virók and A.V. Molnár, eds. 2011. Új magyar füvészkönyv. Magyarország hajtásos növényei. II. Ábrák. Aggteleki Nemzeti Park Igazgatóság, Jósvafő.

Latałowa, M., M. Badura and J. Jarosińska. 2003. Archaeobotanical samples from non-specific urban contexts as a tool for reconstructing environmental conditions (examples from Elblag and Kołobrzeg, northern Poland). Vegetation History and Archaeobotany 12:93-104. Doi: 10.1007/s00334-003-0011-x

Liu, K., R. J. Eastwood, S. Flynn, R. M. Turner and W. H. Stuppy. 2008. Seed information database. Available at: http://www.kew.org/data/sid. Accessed on September 28, 2014.

Lohmann, J. 1987. Paläo-Ethnobotanische Untersuchungen an Baumaterial von Bauernhäusern des 16.-18. Jh. in der Oberpfalz. Unpublished Doctoral Dissertation. University of Göttingen, Göttingen.

Malone, C.R. 1967. A rapid method for enumeration of viable seeds in soil. Weeds 15:381-382.

Marinova, E., G. J. M. van Loon, M. De Meyer and H. Willems. 2012. Plant economy and land use in Middle Egypt during the late Antique/early islamic period: archaeobotanical analysis of mud bricks and mud plasters from the area of Dayr al-Barshā. Reports in African Archaeology 3:120-136.
Martin, A.C. and W.D. Barkley. 1961. Seed identification manual. University of California Press, Los Angeles, CA.

Matthews, W. 2010. Geoarchaeology and taphonomy of plant remains and microarchaeological residues in early urban environments in the Ancient Near East. Quaternary International 214:98-113. Doi: 10.1016/ j.quaint.2009.10.019.

McGovern, P. E., T. L. Sever, J.W. Myers, E.E. Myers, B. Bevan, N.F. Miller, S. Bottema, H. Hongo, R.H. Meadow, P.I. Kuniholm, S.G.E. Bowman, M.N. Leese, R.E.M. Hedges, F.R. Matson, I.C. Freestone, S.J. Vaughan, J. Henderson, P.B. Vandiver, C.S. Tumosa, C.W. Beck, P. Smith, A.M. Child, A.M. Pollard, I. Thuesen and C. Sease. 1995. Science in Archaeology: A Review. American Journal of Archaeology 99:79-142. Doi: 10.2307/506880

Miller, N. F. 1989. What mean these seeds: a comparative approach to archaeological seed analysis. Historical Archaeology 23:50-58.

Newton, C. 2004. Plant tempering of Predynastic pisé at Adaïma in Upper Egypt: building material and taphonomy. Vegetation History and Archaeobotany 13:55 -64. Doi: 10.1007/s00334-003-0025-4

O’Rourke, M. K. 1983. Pollen from adobe brick. Journal of Ethnobiology 3:39-48.

Paušič, I., S. Škornik, M. Culiberg and M. Kaligarič. 2010. Weed diversity in cottage building material used in the 19 $9^{\text {th }}$ century: past and present of the plant occurrence. Polish Journal of Ecology 58:577-583.

Pearsall, D. M. 2000. Paleoethnobotany. A handbook of procedures, $2^{\text {nd }}$ edition. Left Coast Press, Walnut Creek (CA).

Pennington, H. L. and S. A. Weber. 2004. Paleoethnobotany: modern research connecting ancient plants and ancient people. Critical Reviews in Plant Science 23:13-20. Doi: 10.1080/07352680490273220.

Radics, L., ed. 1998. Gyommaghatározó. Mezőgazda Kiadó, Budapest.

Renfrew, J. M. 1973. Palaeoethnobotany: the prehistoric food plants of the Near East and Europe. Columbia University Press, New York, NY.

Rösch, M. and E. Fischer. 1999. Pflanzenreste aus einer Lehmwand als Dokumente von Landwirtschaft und Ernährung im 14. Jahrhundert. 
In: Unter Putz und Pflasterstein: Bauforschung und Mittelalterarchäologie in Reutlingen, edited by Anon., pp. 126-138. Heimatmuseum Reutlingen.

Schermann, S. 1967. Magismeret I-II. Akadémiai Kiadó, Budapest.

Stewart, R. B. and W. Robertson III. 1971. Moisture and seed carbonization. Economic Botany 30:381.

van Bergen, P. F., H. A. Bland, M. C. Horton and R. P. Evershed. 1997. Chemical and morphological changes in archaeological seeds and fruits during preservation by desiccation. Geochimica et Cosmochimica Acta 61:1919-1930. Doi: 10.1016/S00167037(97)00051-3.

van der Veen, M. 1999. The economic value of chaff and straw in arid and temperate zones. Vegetation History and Archaeobotany 8:211-224. Doi: 10.1007/ BF02342721.

van der Veen, M. 2007. Formation processes of desiccated and carbonized plant remains - the identification of routine practice. Journal of Archaeological Science 34:968-990. Doi: 10.1016/ j.jas.2006.09.007.

Vandorpe, P. and S. Jacomet. 2007. Comparing different pre-treatment methods for strongly compacted organic sediments prior to wet-sieving: a case study on Roman waterlogged deposits. Environmental Archaeology 12:207-214. Doi: 10.1179/174963107x226462.

Willerding, U. 1996. Zur Vervendung von Pflanzen im Hausbau des Mittelalters und während der Neuzeit. In Beiträge zur Ur-und Frühgeschichte Mitteleuropas, Band 9. Terra \& Praehistoria. Festschrift für K.-D. Jäger, edited by S. Ostritz and R. Einicke, pp. 117-123. WilkauHasslau, Halle.

Zohary, D., Hopf, M. and E. Weiss. 2012. Domestication of plants in the old world, $4^{\text {th }}$ edition. Oxford University Press, New York, NY.

Supplementary Files are linked to the online version of the paper at ojs.ethnobiology.org/index.php/ebl.

\section{Biosketches}

Tamás Henn is a PhD student in the Department of Ecology at the University of Pécs, Hungary. He is currently working on the examination of desiccated seed assemblages from natural building materials in Southwestern Hungary.

Róbert W. Pál is an associate professor in the Department of Ecology at the University of Pécs, Hungary. He is currently working on the study of invasive plant species in a biogeographic perspective. 
Appendix

A

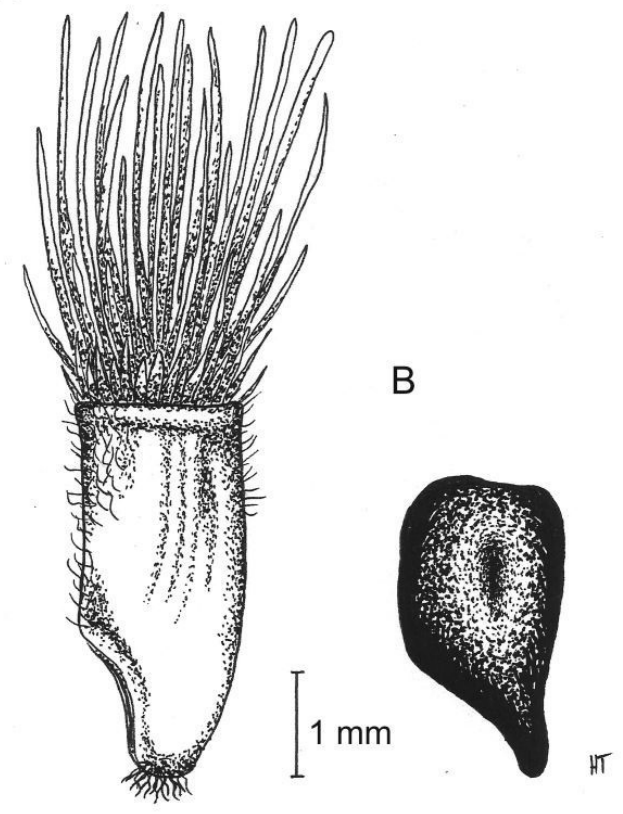

Photo 1. Intact (A) achene and eroded seed (B) of Centaurea cyanus.

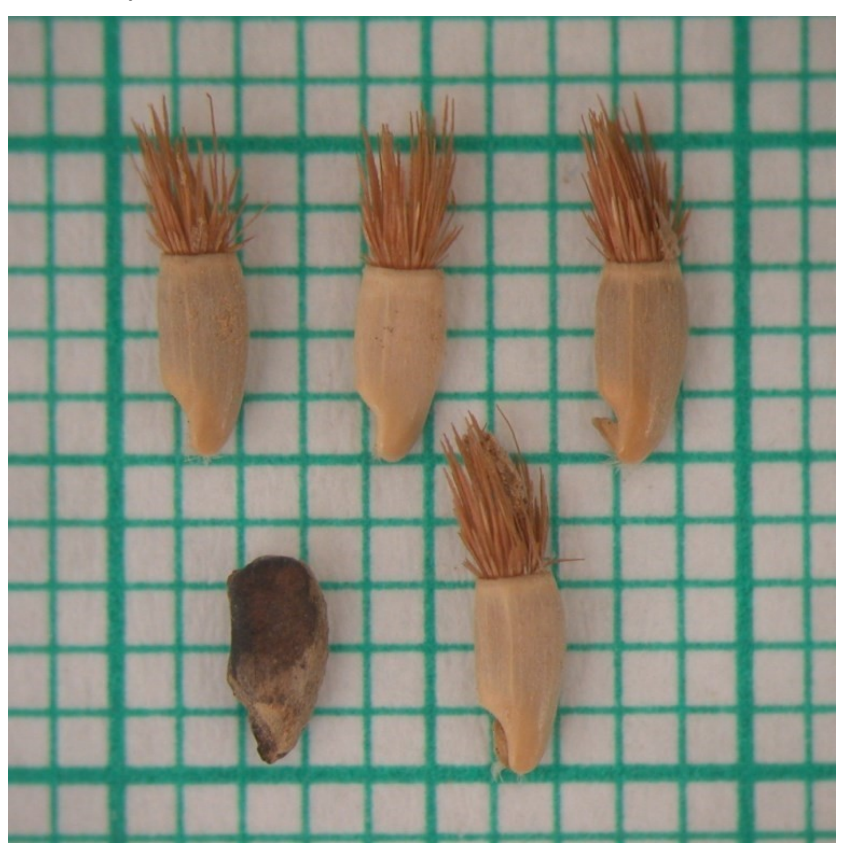

Photo 2. Achenes of Centaurea cyanus found in sample AB02 (Véménd).
A

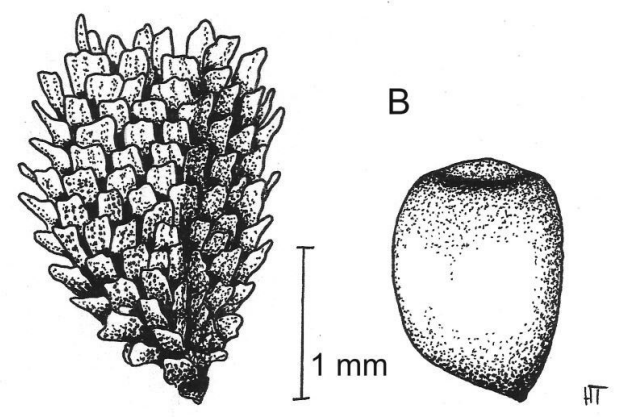

Photo 3. Intact (A) and abraded seed (B) of Consolida regalis.

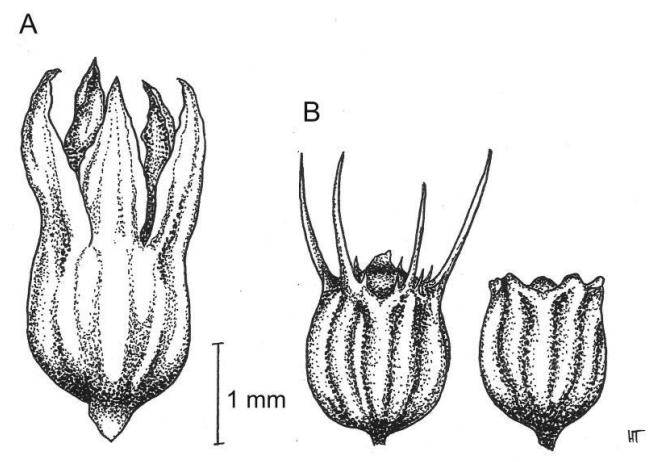

Photo 4. Intact (A) and abraded capsules (B) of Scleranthus annuus.

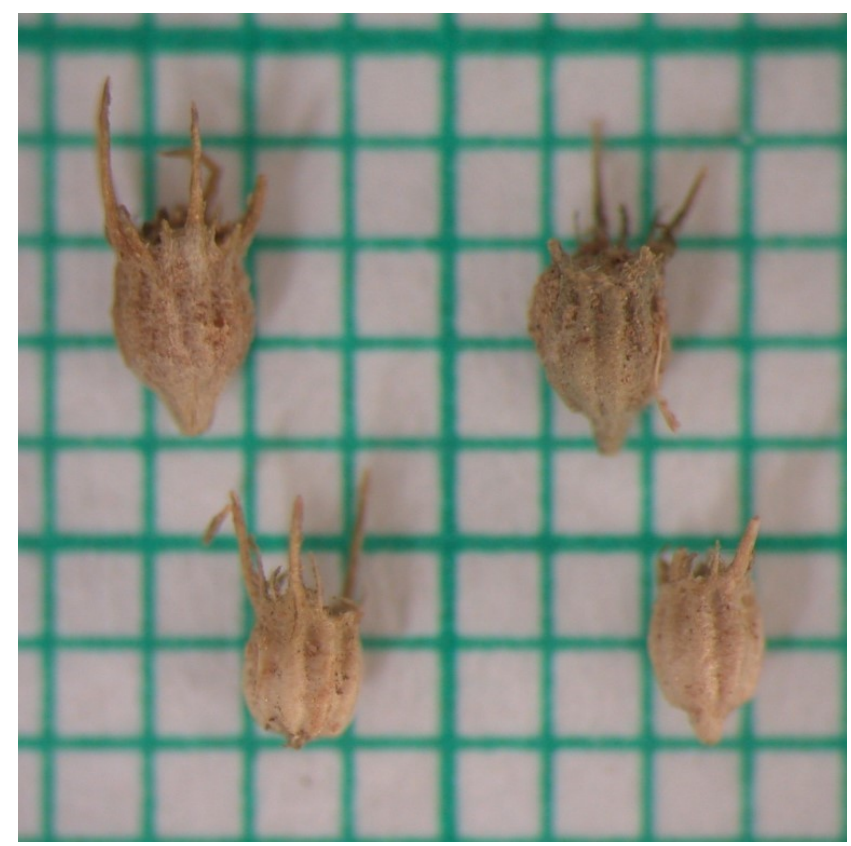

Photo 5. Deformed diaspores of Scleranthus annuus found in sample AB34 (Abaliget). 


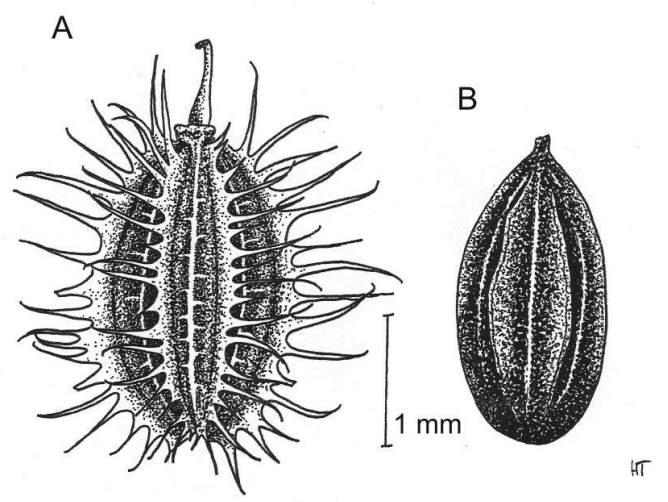

Photo 6. Intact (A) and abraded polachenarium (B) of Daucus carota ssp. carota. 